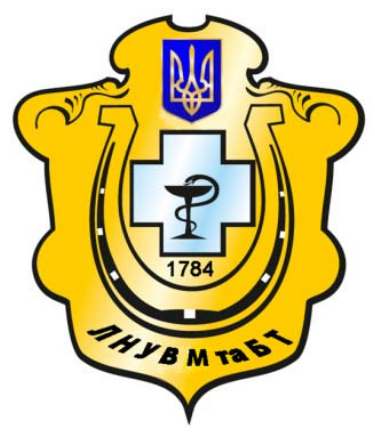

Науковий вісник Львівського національного університету ветеринарної медицини та біотехнологій імені С.3. Гжицького

Scientific Messenger of Lviv National University of Veterinary Medicine and Biotechnologies named after S.Z. Gzhytskyj

doi:10.15421/nvlvet7335

ISSN 2518-7554 print

ISSN 2518-1327 online

$\underline{\text { http://nvlvet.com.ua/ }}$

УДК 502.2:599.5:359

\title{
Визначення динаміки погодних умов протягом календарного року в прибережних ділянках акваторії Одеської затоки з метою утримання морських ссавців у відкритих вольсрах
}

\author{
Т.А. Кобзар, С.В. Мазовська \\ ndc_d_okeanarium_ndu_1@ukr.net \\ Науково-дослідний центр Збройних Сил Украӥни «Державний океанаріум», \\ вул. Фонтанська дорога, 4, м. Одеса, 65009, Україна
}

\begin{abstract}
У статті наведені дані щодо динаміки погодних умов у прибережних ділянках акваторії Одеської затоки протягом календарного року. Дослідження проводились в рамках науково-дослідної роботи НДЦ ЗС України «Державний океанаріум» $з$ метою визначення оптимального місия розташування відкритих вольєрів для утримання морських ссавиів у прибережній акваторії. Відповідно до вимог дійсних керівних документів, щодо утримання морських ссавців в умовах неволі, відкриті конструкиї вольєрів повинні розміщуватись у чистих природних акваторіях, гарантовано захищених від штормів, прибійної хвилі та впливу антропогенного забруднення. В основу проведених досліджень покладені офіиійні дані, надані Гідрометеорологічним центром Чорного та Азовського морів (Державна служба Украӥни з надзвичайних ситуачій) щзодо динаміки температури повітря й морської води та змін погодних умов у прибережних ділянках акваторії Одеської затоки протягом останніх років. Протягом терміну досліджень, в даному районі спостерігались максимальні підвищення температури повітря до $38,1{ }^{\circ} \mathrm{C}$ та морської води до $28,6{ }^{\circ} \mathrm{C}$ у літній період, щзо перевищує допустимі норми для утримання дельфінів 8 умовах відкритих акваторій. Найбільше зниження температури повітря у зимовий період реєструвались в січні $і$ лютому. Відповідно до иього, знижувалась температура морської води та відзначалась поява плавучої форми криги. Цей факт $є$ також надзвичайно несприятливим, за умови утримання морських ссавиів у відкритій акваторії в зимовий період.

При проектуванні споруд відкритих вольєрів для утримання морських тварин також необхідно обов'язково враховувати показники максимальної сили вітру та основні його напрямки на досліджуваних ділянках. Відповідно до отриманих даних, утримання морських тварин у відкритих вольєрах в ділянці акваторії Одеської затоки можсливо лише сезонно. Альтернативним ріменням даного питання може бути комбінований тип утримання: переведення морських тварин до приміщення критого басейну з природною очищеною морською водою за значного зниження температури повітря й утворення криги у зимовий період або за невідповідності морської води основним санітарно-епідеміологічним вимогам.

Ключові слова: морські ссавиі, утримання, відкриті вольєри, Одеська затока, погодні умови, температура, повітря, морська вода, атмосферні опади, льодостав.
\end{abstract}

\section{Определение динамики погодных условий в течение календарного года на прибрежных участках акватории Одесского залива с целью содержания морских млекопитающих в открытых вольерах}

\author{
Т.А. Кобзарь, С.В. Мазовская \\ ndc_d_okeanarium_ndu_1@ukr.net
}

Научно-исследовательский цеентр Вооруженных Сил Украины «Государственньй океанариум», ул. Фонтанская дорога, 4, г. Одесса, 65009, Украина

\section{Citation:}

Kobzar, T.A., Mazovskaya, S.V. (2017). Determination of the weather conditions dynamics within a year in coastal areas of Odessa Bay, with the aim of keeping marine mammals in open enclosures. Scientific Messenger LNUVMBT named after S.Z. Gzhytskyj, 19(73), 169-172. 
В статье приведены данные относительно динамики погодных условий в прибрежных участках акватории Одесского залива в течение календарного года. Исследования проводились в рамках научно-исследовательской работь НИЦ ВС Украины «Государственный океанариум» с иелью определения оптимального места расположения открытых вольеров для содержания морских млекопитающих в прибрежной акватории. В соответствии с требованиями действующих руководящиих документов, по содержанию морских млекопитающих в условиях неволи, открытые конструкции вольеров должнь размещаться в чистых природных акваториях, гарантированно защчищенных от штормов, прибойной волны и воздействия антропогенного загрязнения. В основу проведенных исследований легли официальные данные, предоставленные Гидрометеорологическим иентром Черного и Азовского морей (Государственная служба Украины по чрезвычайным ситуациям) по динамике температуры воздуха и морской воды, изменениям погодных условий в прибрежных участках акватории Одесского залива в течение последних лет. За время исследований, в данном районе наблюдались максимальные повыиения температуры воздуха до $38,1{ }^{\circ} \mathrm{C}$ и морской воды - до $28,6{ }^{\circ} \mathrm{C}$ в летний период, что превынает допустимые нормы для содержания дельфинов в условиях открытых акваторий. Наибольшее снижение температуры воздуха в зимний период регистрировались в январе и феврале. Соответственно, снижалась температура морской воды и отмечалась появление плавающей формы льда. Этот факт является также чрезвычайно неблагоприятным, при условии содержания морских млекопитающих в открытой акватории в зимний период. При проектировании сооружений открытых вольеров для содержания морских животных необходимо обязательно учитывать показатели максимальной силь ветра и основные его направления на исследуемых участках. Согласно полученным данным, возможно только сезонное содержание морских животных в открытых вольерах в районе акватории Одесского залива. Альтернативным решением данного вопроса может быть комбинированный тип содержания: перевод морских животных в помещение крытого бассейна с природной очищенной морской водой, при значительном снижении температуры воздуха и образовании наледи в зимний период или при несоответствии морской воды основным санитарно-эпидемиологическим требованиям.

Ключевые слова: морские млекопитающие, содержание, открытые вольеры, Одесский залив, погодные условия, температура, воздух, морская вода, атмосферные осадки, ледостав.

\title{
Determination of the weather conditions dynamics within a year in coastal areas of Odessa Bay, with the aim of keeping marine mammals in open enclosures
}

\author{
T.A. Kobzar, S.V. Mazovskaya \\ ndc_d_okeanarium_ndu_1@ukr.net \\ Scientific research center of Armed forces of Ukraine «State Oceanarium», \\ Fontanskaya Doroga st., 4, Odessa, 65009, Ukraine
}

The article provides data about the dynamics of weather conditions in the coastal water areas of Odessa Bay by the year. The research was conducted within the framework of the advanced study of research center of the armed forces of Ukraine «State Oceanarium» with the aim of determining the optimal location of open enclosures for marine mammals in coastal waters. In accordance with the requirements of operating leading documents, on maintenance marine mammals in the conditions of captivity, the open constructions of cages must take place in the clean natural waters, assuredly protected from storms, surf wave and influence of anthropogenic pollution. Undertaken studies the official figures given by the Hydrometeorological center of the Black and Azov seas (the State service of Ukraine for emergency situations) on the dynamics of air temperature and sea water, changes in weather conditions in coastal areas of the water area of Odessa Bay in recent years. In times of researches, in this district there were maximal increases of air temperature to $38.1{ }^{\circ} \mathrm{C}$ and sea water to $28.6^{\circ} \mathrm{C}$ in summer, which exceeds possible norms for maintenance of dolphins in the conditions of open water areas. The largest decrease in air temperature in winter was recorded in January and February. Accordingly, the temperature of sea water went down and noted the appearance of floating ice shape. This fact is also very unfavorable, on condition of maintenance of marine mammals in the open waters in winter. This fact is also very unfavorable, under condition of marine mammals in the open waters in winter. Constructing open-air cages for marine animals must necessarily include a measure of the maximal strength of the wind and the main directions on the investigated areas. According to the obtained data, there is only seasonal maintenance of marine animals in open-air cages can be applied in the district of waters of the Odessa Bay. The alternative decision of this question can be the combined type of maintenance: moving of marine animals in the apartment of the covered pool with the natural cleared sea water, at the considerable decline of temperature of air and the formation of ice in winter or at disparity of sea water to the main sanitary and epidemiological requirements.

Key words: marine mammals, table of contents, open enclosures, Odessa Bay, weather conditions, temperature, air, sea water, atmospheric rainfalls, ice.

\section{Вступ}

У 2014 році, в наслідок анексії Кримського півострову, Науково-дослідний центр Збройних Сил України «Державний океанаріум» був офіційно передислокований з м. Севастополь (бухта Козача) до м. Одеса.

Одним з напрямів роботи даної державної установи $є$ утримання й використання морських ссавців, зокрема в інтересах ВМС ЗС України, тому виникла потреба у визначенні нового місця розташування вольєрів для їх утримання. При розгляді можливос- тей, щодо розміщення дельфінів та сивучів в умовах акваторії Одеської затоки, слід враховувати, що за своїми ландшафтними особливостями, погодними умовами та складом морської води ця ділянка Чорного моря суттєво різниться 3 Південним узбережжям Криму.

Мета досліджень - визначення найбільш відповідного місця (в межах узбережжя Одеської затоки) для обладнання відкритих вольєрів для утримання морських ссавців, у тому числі, в інтересах ВМС ЗС України. 


\section{Матеріал і методи досліджень}

Дослідження проводились у 2015 році в межах науково-дослідної роботи «Дослідження параметрів навколишнього середовища для утримання морських тварин в умовах акваторії Одеської затоки в інтересах ВМС 3С України» на базі Науково-дослідного центру Збройних Сил України «Державний океанаріум», «Одеського обласного лабораторного центру держсанепідслужби України» та Гідрометеорологічного центру Чорного та Азовського морів (Державна служба України з надзвичайних ситуацій).

Метод дослідження - моніторинг та аналіз отриманих даних щодо динаміки температур води і повітря та змін погодних умов протягом календарного року у прибережних ділянках акваторії Одеської затоки для визначення відповідного місця утримання морських тварин.

\section{Результати та їх обговорення}

Відповідно до вимог дійсних керівних документів, щодо утримання морських ссавців в умовах неволі, відкриті конструкції вольєрів (огороджені пальовосітчастими стінками) повинні розміщуватись у чистих природних акваторіях, гарантовано захищених від штормів, прибійної хвилі та впливу антропогенного забруднення (The order of the Ministry of Ecology and Natural Resources of Ukraine dated 06.12.2012 № 622).

Одеська затока розташована між мисом Ланжерон та мисом Північний Одеський. Західний та північнозахідний береги затоки є низькими, а північний -

високий та кручастий. Північно-західна частина затоки має глибини менше 10 м, південно-західна частина $\epsilon$ глибоководною, що дозволяє використовувати іії для підходу морських суден. У південно-західній частині Одеської затоки розташований Одеський морський порт, який є одним 3 найпотужніших в Україні. Південна частина затоки використовується виключно для рекреаційних потреб. Клімат регіону - помірно континентальний, порівняно сухий, 3 м'якою зимою i теплим (іноді спекотним) літом та інтенсивними вітрами. Кількість сонячних днів протягом року перевищує 290. Середньорічна температура повітря складає $10,1^{\circ} \mathrm{C}$. Зима коротка і м'яка, з середньою температурою близько $0{ }^{\circ} \mathrm{C}$. Сніг і температури нижчі за $-10{ }^{\circ} \mathrm{C}$ спостерігаються рідко. Літо тривале і жарке, середня температура близько $25^{\circ} \mathrm{C}$. Нерідкими є температури вищі за $35^{\circ} \mathrm{C}$. Найбільше ясних днів в даному районі - в серпні, менше всього - в грудні (Êlozína, 1996).

За даними Гідрометеорологічного центру Чорного та Азовського морів (Державної служби України 3 надзвичайних ситуацій) протягом 2010-2014 років найбільш виражені коливання показників температури повітря та морської води в ділянці прибережної акваторії Одеської затоки визначались у 2010 та 2012 роках. Найнижча температура повітря в зимовий період: $-20,6{ }^{\circ} \mathrm{C}$ реєструвались в січні у 2010 року та $18,6^{\circ} \mathrm{C}$ в лютому в 2012 року (табл. 1).

У ці ж роки показник температури морської води в ділянці прибережної акваторії Одеської затоки знижувався до $2,3{ }^{\circ} \mathrm{C}$ i $0,8{ }^{\circ} \mathrm{C}$, відповідно (Míkhal'ov, 2015).

Таблиия 1

Річні мінімальні та максимальні показники температури повітря в акваторії Одеської затоки протягом календарного року, ${ }^{\circ} \mathrm{C}$

\begin{tabular}{|c|c|c|c|c|c|c|c|c|c|c|}
\hline \multirow{2}{*}{ Місяць } & \multicolumn{2}{|c|}{2010 рік } & \multicolumn{2}{|c|}{2011 рік } & \multicolumn{2}{c|}{2012 рік } & \multicolumn{2}{c|}{2013 рік } & \multicolumn{2}{c|}{2014 рік } \\
\cline { 2 - 11 } & $\min$ & $\max$ & $\min$ & $\max$ & $\min$ & $\max$ & $\min$ & $\max$ & $\min$ & $\max$ \\
\hline січень & $-20,6$ & $-2,8$ & $-10,7$ & 8,2 & $-14,3$ & 8,1 & $-12,7$ & 12,4 & $-16,4$ & 13,4 \\
\hline лютий & $-8,2$ & 8,5 & $-11,5$ & 12,5 & $-18,6$ & 10,0 & $-2,6$ & 11,0 & $-12,2$ & 11,0 \\
\hline березень & $-5,9$ & 21,1 & $-9,6$ & 18,3 & $-5,6$ & 22,8 & $-8,3$ & 15,8 & 0,6 & 19,6 \\
\hline квітень & 3,7 & 18,4 & 0,7 & 21,3 & 0,6 & 29,0 & 3,1 & 26,0 & 0,0 & 21,8 \\
\hline травень & 9,9 & 26,0 & 5,7 & 26,3 & 10,3 & 30,1 & 12,9 & 28,0 & 5,1 & 29,6 \\
\hline червень & 14,3 & 30,8 & 12,7 & 30,5 & 12,9 & 35,1 & 12,7 & 31,5 & 11,1 & 32,1 \\
\hline липень & 17,1 & 32,9 & 13,7 & 33,8 & 16,1 & 35,6 & 14,8 & 32,2 & 15,7 & 32,3 \\
\hline серпень & 14,4 & 38,1 & 14,7 & 33,0 & 12,6 & 36,7 & 12,4 & 33,5 & 13,6 & 34,4 \\
\hline вересень & 10,5 & 25,6 & 9,1 & 30,4 & 11,0 & 27,5 & 5,7 & 27,7 & 4,6 & 29,3 \\
\hline жовтень & 0,1 & 19,2 & 0,5 & 27,0 & 4,5 & 24,6 & 0,9 & 21,4 & 0,1 & 21,6 \\
\hline листопад & 1,2 & 22,1 & $-2,6$ & 12,0 & $-1,4$ & 17,8 & $-4,8$ & 18,6 & $-3,4$ & 15,2 \\
\hline грудень & $-9,7$ & 12,3 & $-5,3$ & 14,4 & $-12,6$ & 13,6 & $-7,4$ & 9,3 & $-12,7$ & 14,8 \\
\hline
\end{tabular}

Максимальні підвищення температури повітря в даному районі також були зафіксовані у 2010 та 2012 роках: $38,1^{\circ} \mathrm{C}$ у серпні 2010 року та $36,7^{\circ} \mathrm{C}$ в цьому ж місяці 2012 року (табл. 1). Температура морської води в дані періоди складала $28,6^{\circ} \mathrm{C}$ та $25,9{ }^{\circ} \mathrm{C}$, відповідно (Míkhal'ov, 2015). Згідно наказу Міністерства екології та природних ресурсів України від 06.12.2012 року № 622 «Про затвердження Правил і норм утримання дельфінів в умовах неволі» в дельфінаріях (океанаріумах) відкритих конструкцій температура води має бути в межах від 15 до $25^{\circ} \mathrm{C}$, допустимо лише короткочасне ii коливання (до 60 хв.) у межах 8-28 ${ }^{\circ} \mathrm{C}$. 3 метою захисту тварин від інтенсив- ного сонячного опромінювання у літній період або атмосферних опадів протягом календарного року, відкриті конструкції дельфінаріїв мають бути обладнані постійними навісами або розбірними тентами.

Згідно отриманих даних, в період 32010 по 2014 роки появу плавучої форми криги в ділянці прибережної акваторії Одеської затоки в зимовий період реєстрували у 2010-2012, 2014 роках, лише у 2013 води акваторії залишалися вільними (табл. 2). Поява будь-якої форми криги в акваторії $є$ несприятливим фактором за умови утримання морських тварин у відкритих вольєрах (Míkhal'ov, 2015). 
Терміни наявності льодоставу в ділянці узбережжя Одеської затоки

\begin{tabular}{|c|c|c|c|c|c|c|}
\hline $\begin{array}{c}\text { Місце } \\
\text { визначення }\end{array}$ & Утворення криги & 2010 рік & 2011 рік & 2012 рік & 2013 рік & 2014 рік \\
\hline \multirow{4}{*}{ Одеса (затока) } & поява криги & 27.01 . & 20.02 . & 01.02 . & - & 01.02 . \\
\hline & очищення криги & 23.02 & 11.03. & 27.02 & - & 19.02. \\
\hline & форми криги & $\begin{array}{c}\text { плавуча } \\
\text { крига }\end{array}$ & $\begin{array}{c}\text { плавуча } \\
\text { крига }\end{array}$ & $\begin{array}{c}\text { плавуча } \\
\text { крига }\end{array}$ & - & $\begin{array}{c}\text { плавуча } \\
\text { крига }\end{array}$ \\
\hline & $\begin{array}{c}\text { продовження } \\
\text { періоду }\end{array}$ & 27 діб & 15 діб & 26 діб & $\begin{array}{c}\text { утворення } \\
\text { криги не вияв- } \\
\text { лено } \\
\end{array}$ & 18 діб \\
\hline \multirow{4}{*}{ Одеса (порт) } & поява криги & 24.01. & 30.01 . & 30.01 . & - & 01.02 . \\
\hline & очищення криги & 19.01. & 07.03. & 29.02. & - & 19.02. \\
\hline & форми криги & $\begin{array}{c}\text { плавуча } \\
\text { крига }\end{array}$ & $\begin{array}{c}\text { плавуча } \\
\text { крига }\end{array}$ & $\begin{array}{c}\text { плавуча } \\
\text { крига }\end{array}$ & - & $\begin{array}{c}\text { плавуча } \\
\text { крига }\end{array}$ \\
\hline & $\begin{array}{c}\text { продовження } \\
\text { періоду }\end{array}$ & 20 діб & 37 діб & 31 доба & $\begin{array}{c}\text { утворення } \\
\text { криги не вияв- } \\
\text { лено }\end{array}$ & 13 діб \\
\hline
\end{tabular}

Найбільша сила вітрів протягом досліджуваного періоду в ділянці узбережжя Одеської затоки спостерігалась: у 2010 році в січні $(20 \mathrm{~m} / \mathrm{c})$ та липні $(30 \mathrm{~m} / \mathrm{c})$, північного та північно-західного напрямків; у 2011 році - в лютому $(20 \mathrm{M} / \mathrm{c})$, червні $(20 \mathrm{M} / \mathrm{c})$ та жовтні $(20 \mathrm{~m} / \mathrm{c})$, північного, північно-західного та північно-східного напрямків; у 2012 році - в лютому $(22 \mathrm{~m} / \mathrm{c})$, липні $(20 \mathrm{~m} / \mathrm{c})$ та грудні $(22 \mathrm{~m} / \mathrm{c})$, східного, північно-східного та північного напрямку; у 2013 році - в березні $(21 \mathrm{~m} / \mathrm{c})$ та червні (31 м/с), південного та південно-східного напрямку; у 2014 році - в січні, червні, жовтні та грудні $(20 \mathrm{~m} / \mathrm{c})$, північно-східного, північно-західного та південно-західного напрямків (Tuchkovenko, 2002; Míkhal'ov, 2015).

Отримані дані, щодо максимальної сили вітру та основних його напрямків на досліджуваних ділянках прибережної акваторії необхідно обов'язково враховувати при проектуванні споруд відкритих вольєрів для утримання морських тварин, розрахуванні їх міцності та стійкості до навантажень.

\section{Висновки}

Отже, враховуючи зазначене вище, утримання морських тварин у відкритих вольєрах в ділянці акваторії Одеської затоки (відповідно до вимог керівних документів) можливо лише сезонно, протягом 6-8 місяців календарного року. Альтернативним рішенням даного питання може бути комбінований тип утримання: переведення морських тварин до приміщення критого басейну з природною очищеною морською водою, за умови значного зниження температури повітря й утворення криги у зимовий період або за невідповідності морської води основним санітарноепідеміологічним вимогам.

Перспективи подальших досліджень. Враховуючи зазначене вище, вважаємо за доцільне, проведення додаткових досліджень в інших ділянках акваторії Чорного моря (поза межами міста Одеси), 3 метою визначення найбільш сприятливого місця для розміщення морських тварин у відкритих вольєрах та створення оптимальних умов для їх існування й використання протягом всього календарного року, зокрема в інтересах ВМС ЗС України.

\section{Бібліографічні посилання}

The order of the Ministry of Ecology and Natural Resources of Ukraine dated 06.12.2012 № 622 «Pro zatverdzhennya Pravil í norm utrimannya del'fínív $\mathrm{v}$ umovakh nevolí» (in Ukrainian).

Êlozína, O.M. (1996). Yefektivníst' vikoristannya rekreatsíynikh resursív (na prikladí Odes'koî oblastí): avtoref. dis. kand. yekon. nauk: spets. Odessa, 18 (in Ukrainian).

Míkhal'ov, Y.O. (2015). Doslídzhennya parametrív navkolishn'ogo seredovishcha dlya utrimannya mors'kikh tvarin v umovakh akvatoríi Odes'koî zatoki v ínteresakh VMS ZS Ukraïni. Zvít $z$ NDR, shifr «Faktor». píd ker. YU.O. Míkhal'ova. № gosreg. 0101U0001937, NDTS ZSU «Derzhavniy okeanaríum». 82 (in Ukrainian).

Tuchkovenko, Yu.S. (2002). Matematicheskaya model' dlya rascheta vetrovykh techeniy v Odesskom regione severo-zapadnoy chasti Chernogo morya. Meteorologiya. 45, 107-117 (in Russian).

Стаття надійшла до редакиії 10.03.2017 